January 1985

\title{
List of Editors
}

Follow this and additional works at: https://jdc.jefferson.edu/jeffjpsychiatry

Part of the Psychiatry Commons

\section{Let us know how access to this document benefits you}

\section{Recommended Citation}

(1985) "List of Editors," Jefferson Journal of Psychiatry. Vol. 3 : Iss. 1 , Article 1.

Available at: https://jdc.jefferson.edu/jeffjpsychiatry/vol3/iss1/1

This Article is brought to you for free and open access by the Jefferson Digital Commons. The Jefferson Digital Commons is a service of Thomas Jefferson University's Center for Teaching and Learning (CTL). The Commons is a showcase for Jefferson books and journals, peer-reviewed scholarly publications, unique historical collections from the University archives, and teaching tools. The Jefferson Digital Commons allows researchers and interested readers anywhere in the world to learn about and keep up to date with Jefferson scholarship. This article has been accepted for inclusion in Jefferson Journal of Psychiatry by an authorized administrator of the Jefferson Digital Commons. For more information, please contact: JeffersonDigitalCommons@jefferson.edu. 


\section{THE JEFFERSON JOURNAL OF PSYCHIATRY}

CHIEF EDITOR

ASSISTANT EDITOR

ASSISTANT EDITOR

ASSISTANT EDITOR

ASSISTANT EDITOR

ASSISTANT EDITOR

ASSISTANT EDITOR

FORMER EDITORS

COVER DESIGN

FACULTY ADVISOR

ADMINISTRATIVE ASSISTANT
John Matt Dorn, M.D.

Fourth-year Resident

James Stanch, M.D.

Third-year Resident

David Mitchell, M.D.

Second-year Resident

Sharon Riser, M.D.

Second-year Resident

Jeffrey Sarnoff, M.D.

Second-year Resident

Peter PreMaria, Jr., M.D.

First-year Resident

Arvin Mirow, M.D.

First-year Resident

Jessica Byrne, M.D.

Kenneth Certa, M.D.

John Clayton, D.O.

Karl Doghramji, M.D.

Jeffrey Sarnoff, M.D.

Harvey J. Schwartz, M.D.

Debra S. Kohler

The Jefferson Journal of Psychiatry is published biannually by the Residency Training Program of the Department of Psychiatry of Jefferson Medical College, 1015 Walnut Street, Philadelphia, Pennsylvania 19107

Copyright 1985 Department of Psychiatry, Jefferson Medical College 